\title{
Diversity of bivalves in Tanjung Balai Asahan Waters, North Sumatra, Indonesia
}

\author{
IPANNA ENGGAR SUSETYA ${ }^{1, \boldsymbol{},}$, DESRITA ${ }^{1}$, ERYANA DHALIA DRAJAD GINTING ${ }^{1}$, MASRIAN FAUZAN $^{1}$, \\ ERI YUSNI ${ }^{1}$, SITI AISYAH SARIDU ${ }^{2}$ \\ ${ }^{1}$ Department of Aquatic Resources Management, Faculty of Agriculture, Universitas Sumatera Utara. J1. Prof A. Sofyan No. 3, Medan 20155, North \\ Sumatra, Indonesia. Tel./Fax.+661-821-3236, `email: ipanna@usu.ac.id \\ ${ }^{2}$ Program of Marine Ecotourism, Akademi Komunitas Kelautan dan Perikanan Wakatobi. Wakatobi, Southeast Sulawesi, Indonesia
}

Manuscript received: 28 October 2017. Revision accepted: 24 May 2018.

\begin{abstract}
Susetya IE, Desrita, Ginting EDD, Fauzan M, Yusni E, Saridu SA. 2018. Diversity of bivalves in Tanjung Balai Asahan Waters, North Sumatra, Indonesia. Biodiversitas 19: 1147-1153. Local and regional market demands for bivalves increase outside Tanjung Balai City and Asahan District Waters, North Sumatra, Indonesia. As a result, high exploitation of bivalves occurred. In the other hand, there were less comprehensive information and studies on the diversity of bivalves in this area. This study aimed to determine the diversity of bivalves and water quality of Tanjung Balai Asahan Waters; was conducted between July 2016 and November 2017. Sampling of bivalves was conducted monthly. Several physical and chemical parameters were quantified. Data analysis included community structure analysis and Principal Component Analysis (PCA). The result showed that there were 16 species of bivalves from 7 families in Tanjung Balai Asahan Waters. Station 2 had the highest composition of bivalves, while the lowest was noted at Station 1. The mean abundance of bivalves at stations 1,2 and 3 were $352 \pm 22 \mathrm{ind} / \mathrm{m}^{2}, 222 \pm 14 \mathrm{ind} / \mathrm{m}^{2}$ and $388 \pm 30,2 \mathrm{ind} / \mathrm{m}^{2}$, respectively. In general, the index of diversity was categorized as low to moderate. The evenness index was categorized as low to high, while the dominance index indicated the absence of dominant species at almost all stations except station 1 . Water quality of the waters was still in capacity to support the life of bivalves. Based on PCA analysis, it was obtained that the abundance of bivalves was positively correlated with nitrite, nitrate, phosphate, salinity, and $\mathrm{pH} . \square$
\end{abstract}

Keywords: Abundance, Asahan, bivalves, diversity, PCA, Tanjung Balai

\section{INTRODUCTION}

Marine and fishery potential of North Sumatra, Indonesia consist of potency of capture fisheries and aquaculture, in which potency of catch fishery consist of potential of Malacca Strait (east coast) of 276.030 tons/year and potential of Indian Ocean (west coast) of 1.076 .960 tons/year. Aquaculture production consists of 20.000 ha ponds, marine aquaculture of 100.000 ha, freshwater cultivation of $81.372,84$ ha and public waters of 155.797 ha (Department Fisheries and Marine of North Sumatra Province 2014).

Tanjung Balai Asahan Waters are located in the east of North Sumatra, Indonesia with Malacca Strait bordering to the north and east, North Labuhan Batu District to the south and Tanjung Balai City to the west. These areas mostly include Teluk Nibung and East Sei Kepayang subdistricts of Asahan District. These waters are potential waters with freshwater input from Asahan River and other small rivers that can transfer nutrients from the mainland as well as bringing domestic and industrial wastes (Intan et al. 2013). Tanjung Balai Asahan Waters have a high potential and provide many marine products for North Sumatra because of this area is a fishing ground of some commodities, such as fish, shrimp, mollusks (bivalves and gastropod) and crab (Fauzan et al. 2018).

As much as seven species of mollusks were found in the waters of Tanjung Balai Asahan, such as Anadara granosa, A. maculosa, A. antiquata, Mytilus viridis, Pectin sp., Tivela stultorum and Strombus sp. (Intan et al. 2013). Six out of them were bivalves and one was gastropod. Besides, Fauzan et al. (2018) state that species of bivalves in Tanjung Balai Asahan Waters, especially in the intertidal zone, are Anadara granosa, A. gubernaculum, Perna viridis, and Meretrix meretrix.

One of the most widely used fisheries potential commodities is bivalves. Bivalves are one of the most common groups of invertebrate organisms and inhabit intertidal regions (Manzo et al. 2014; Walag and Canencia 2016). This group is known for its special adaptation that allows it to survive the areas in which physical and chemical stress are attained. In addition, bivalves also have adaptation mechanism against currents and waves. However, they have no ability to move quickly (motile), making them very easy to catch (Robson et al. 2010).

Bivalves have been exploited for various purposes, ecologically, economically, or other purposes (Srimariana 2015). Bivalves act as constituents in the food chain in an ecosystem. The economic benefits of bivalves are as food sources, and their shells are used as decoration (Mikkelsen and Henne 2011). Bivalves are also a source of tasty and nutritious food with high protein content yet low prices in India and Southeast Asia (Jagadis and Rajagopal 2007). Bivalves are also used as bioindicator for their slow movement and sedentary life (Guijarro et al. 2015; Dabwan and Taufiq 2016; Azizi et al. 2018). 
Bivalves are a fishing commodity favored by the locals of Tanjung Balai City and Asahan District. Its presence is abundant in nature, but the fishermen exploit with various sizes both big and small without considering its sustainability. Increasing demand for bivalves in the market in meeting both local and regional needs outside the area has led to the exploitation that tended to neglect the principles of sustainability of natural resources. Increased fishing activity has brought about the pressure on bivalve populations and emerged the concern about the sustainability of bivalves in the area. To date, there was no comprehensive information and no study available on the diversity of bivalves in the waters of Tanjung Balai Asahan. The purpose of this research was to gather information about the diversity of bivalves in this area.

\section{MATERIALS AND METHODS}

\section{Study area}

The study was conducted in September to November 2017 in the waters of Tanjung Balai City and Asahan District, North Sumatra, Indonesia. Sampling of bivalves and water quality was conducted on monthly basis.
Research site was divided into 3 stations based on typical area such as estuary area as station 1 , station 2 and 3 as intertidal zone. Station 3 is an intertidal zone near the mainland of the Batubara region (Figure 1). The identification of bivalves was conducted at the Integrated Laboratory of Resource Management, Faculty of Agriculture, University of North Sumatra. Nitrate, nitrite, and phosphate analysis were conducted at the Research Center and Industrial Standardization of Medan. Organic matter and substrate texture were analyzed at the Laboratory of Research and Technology of the Faculty of Agriculture, Universitas Sumatera Utara, Medan, Indonesia.

\section{Procedures}

Bivalves sampling was conducted once a month using a dredge of $0,39 \times 0,24 \mathrm{~m}$ in size. The dredge was operated by descending it into the water and then take samples of bivalves. Samples taken are collected on board. Samples were taken three times for each station. Samples were then transported to the laboratory for cleaning and identification. To identify the species, it was used Dharma (2005) as the reference.
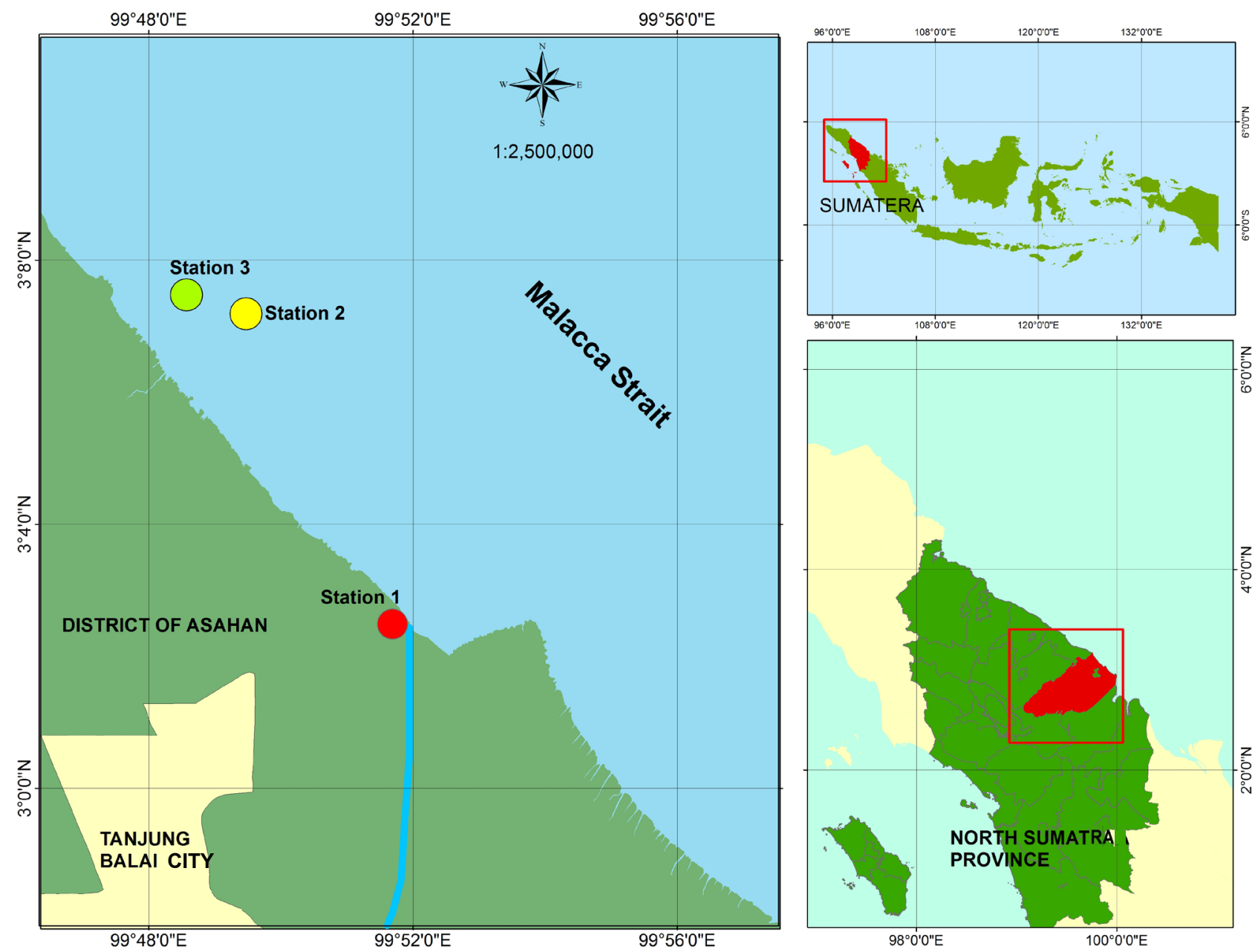

Figure 1. Sampling sites of bivalves in Tanjung Balai Asahan Waters, North Sumatra, Indonesia: Station 1 (03'01'25,47'N-

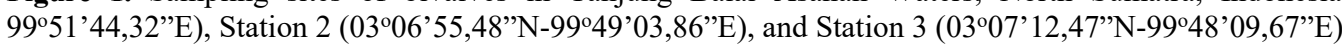


Water parameters were temperature, $\mathrm{DO}, \mathrm{pH}$, salinity, nitrate, nitrite, phosphate, visibility, organic matter and substrate texture. Temperature, DO, $\mathrm{pH}$, salinity and visibility were measured in situ. Water samples were taken for nitrate, nitrite and phosphate analysis in the laboratory. Sediment samples were also collected for organic matter and substrate texture analysis in the laboratory.

\section{Data analysis}

Abundance

Abundance of organism in a water can be expressed as the number of individuals per area. Bivalves abundance was determined following a formula according to Odum and Barrett (2005) as follow:

$$
A=\frac{X i}{n i}
$$

Where,
A : Abundance (Individual $/ \mathrm{m}^{2}$ )
$\mathrm{Xi}$ : The number of individual of species $\mathrm{i}$
ni : wide area

\section{Diversity Index $\left(H^{\prime}\right)$}

Diversity Index is a characteristic of a community that describes the level of species diversity of present organisms in the community. We used Shannon-Wiener's diversity index (Odum and Barrett 2005) with following formula:

$$
H^{\prime}=-\sum p i \log _{2} p i
$$

Where,

H' : Diversity Index

$\mathrm{Pi} \quad$ : Necessary probability for each species $=\mathrm{Xi} / \mathrm{N} \square$

$\mathrm{Xi} \quad$ : Number of individual of species $\mathrm{i} \square$

$\mathrm{N}$ : Number of all individuals encountered

Categories of diversity: $\mathrm{H}^{\prime}<1=$ low, $1<\mathrm{H}^{\prime}<3=$ moderate and $\mathrm{H}^{\prime}>3=$ high

\section{Evenness Index (E)}

Evenness index is the ratio of the value of diversity to the logarithm of the number of species. The formula for evenness index according to Krebs (1989) is:

$$
e=\frac{H^{\prime}}{\log _{2} S}
$$

Where,

E : Evenness Index

$\mathrm{H}^{\prime} \quad$ : Diversity Index

Hmax : $\log _{2} \mathrm{~S}$

$\mathrm{S} \quad$ : Number of species

Categories of evennes: e $<0.4=$ low, $0.4<$ e $<0.6=$ moderate and e $>0.6=$ high

\section{Dominance index $(C)$}

According to Odum and Barrett (2005) the dominance index is the degree to dominance of one, several or many types. The Simpson dominance index formula is:

$$
C=\Sigma\left(\frac{X i}{N}\right)^{2}
$$

Where,

C : Dominance Index

$\mathrm{Xi} \quad$ : Number of individual of species $\mathrm{i}$

$\mathbf{N}$ : Total individual found

Categories of dominance: $0<\mathrm{C}<0.5=$ absence of dominant species, $0.5<\mathrm{C}<1=$ there is dominant species

\section{Principal Components Analysis (PCA)}

Multivariable statistical analysis approach based on Principal Components Analysis (PCA) was conducted to determine the effect of environmental parameters on bivalve abundance. PCA analysis was done using XL stat software program.

\section{RESULTS AND DISCUSSION}

\section{Species composition and abundance}

As much as 16 species of bivalves from 7 families, such as Arcidae, Donacidae, Mactridae Mytilidae, Pinnidae, Tellinidae, and Veneridae, were found in the waters of Tanjung Balai Asahan. Species composition was the highest at station 2 while the lowest was at station 1 . Bivalves Donax faba, Meretrix meretrix and Tapes sulcarius were all found at all stations. The mean abundance of bivalves at station 1, 2 and 3 were $352 \pm 22$ $\mathrm{ind} / \mathrm{m}^{2}, 222 \pm 14 \mathrm{ind} / \mathrm{m}^{2}$ and $388 \pm 30,2 \mathrm{ind} / \mathrm{m}^{2}$, respectively (Table 1). The most abundant species at station 1 was $M$. meretrix, while that at station 2 and 3 corresponded to $T$. sulcarius. Species composition and abundance of bivalves

\begin{tabular}{|c|c|c|c|c|}
\hline \multirow{2}{*}{ Family } & \multirow{2}{*}{ Bivalvia species } & \multicolumn{3}{|c|}{ Abundance (ind $/ \mathbf{m}^{2}$ ) } \\
\hline & & ST 1 & ST 2 & ST 3 \\
\hline \multirow[t]{3}{*}{ Arcidae } & Anadara granosa & 0 & 9 & 8 \\
\hline & Anadara gubernaculum & 0 & 29 & 53 \\
\hline & Anadara inaequivalvis & 0 & 13 & 30 \\
\hline Donacidae & Donax faba & 7 & 34 & 23 \\
\hline Mactridae & Mactra grandis & 81 & 0 & 0 \\
\hline Mytilidae & Modiolus micropterus & 0 & 1 & 0 \\
\hline Pinnidae & Actrina pectinata & 0 & 0 & 0 \\
\hline Tellinidae & Tellina timorensis & 0 & 1 & 0 \\
\hline \multirow[t]{8}{*}{ Veneridae } & Callista erycina & 0 & 0 & 1 \\
\hline & Callista lilacina & 11 & 0 & 0 \\
\hline & Dosinia dilecta & 0 & 7 & 5 \\
\hline & Dosinia variegate & 0 & 1 & 0 \\
\hline & Meretrix meretrix & 245 & 24 & 58 \\
\hline & Paphia gallus & 0 & 11 & 11 \\
\hline & Paphia undulate & 0 & 13 & 47 \\
\hline & Tapes sulcarius & 8 & 78 & 151 \\
\hline \multicolumn{2}{|c|}{ Average abundance of bivalve $/ \mathrm{m}^{2}$} & $352 \pm 22$ & $222 \pm 1<$ & $4388 \pm 30.2$ \\
\hline
\end{tabular}
in Tanjung Balai Asahan Waters are presented in Table 1.

Table 1. Species composition and abundance of bivalves in Tanjung Balai Asahan Waters, North Sumatra, Indonesia 


\section{Diversity, evenness and dominance index}

Diversity, evenness and dominance index described structure community. In general, diversity index of bivalves in Tanjung Balai Asahan Waters was categorized as low to moderate. Moderate diversity index indicated that bivalves' community in Tanjung Balai Asahan Waters was in a good condition. This was in accordance with Akhirianti et al. (2014) which stated that low diversity index means that bivalves community is in a stable condition despite competition between species for food and space. Evenness index was categorized as low to high while dominance index indicated the absence of dominant species at almost all stations except station 1 (Table 2). It was found that M. meretrix was dominant at station 1 .

\section{Water quality and substrate texture}

Water quality measurement in this present study included physical and chemical parameters. From the parameter observed, it was found that the waters were still considered suitable to support bivalves' life. Temperature, salinity, water transparency, $\mathrm{pH}, \mathrm{DO}$ and nitrites were noted to have the lowest value at station 1 while depth, nitrate, phosphate and organic matters were the highest at this station. Salinity and DO were found the highest at Sation 2. The highest $\mathrm{pH}$ and nitrite were at station 3 . Substrate texture at station 1, 2 and 3 was sandy clay, sandy clay loam, and sand, respectively. Water quality values and substrate texture at each station are shown in Table 3. $\square$

Table 2. Diversity, evenness and dominance index

\begin{tabular}{lccc}
\hline Index & \multicolumn{3}{c}{ Station } \\
\cline { 2 - 4 } & $\mathbf{1}$ & $\mathbf{2}$ & $\mathbf{3}$ \\
\hline Diversity $\left(\mathrm{H}^{\prime}\right)$ & 0.63 & 1.77 & 1.59 \\
Category & Low & moderate & moderate \\
Evenness (E) & 0.54 & 0.62 & 0.76 \\
Category & Low & high & high \\
Dominance (C) & 0.71 & 0.50 & 0.42 \\
Category & There was & - & - \\
& dominant species & & \\
\hline
\end{tabular}

Table 3. Water quality values and substrate texture in Tanjung Balai Asahan Waters, North Sumatra, Indonesia $\square$

\begin{tabular}{lccc}
\hline \multirow{2}{*}{ Water quality } & \multicolumn{3}{c}{ Station } \\
\cline { 2 - 4 } & $\mathbf{1}$ & $\mathbf{2}$ & $\mathbf{3}$ \\
\hline & & & \\
Physical parameters & & 30.38 & 30.69 \\
Temperature $\left({ }^{\circ} \mathrm{C}\right)$ & 29.88 & 32.7 & 32.4 \\
Salinity (\%) & 0.79 & 0.95 & 0.93 \\
Water transparency (m) & 0.58 & 2.61 & 1.18 \\
Depth of water (m) & 4.78 & & \\
& & & \\
Chemical parameters & & 7.91 & 8.06 \\
pH & 7.28 & 5.36 & 4.93 \\
DO (mg/L) & 4.63 & 1.29 & 1.87 \\
Nitrate (mg/L) & 2.99 & 0.044 & 0.050 \\
Nitrite (mg/L) & 0.024 & 0.019 & 0.025 \\
Phosphate (mg/L) & 0.048 & 0.71 & 0.38 \\
Organic matter $(\%)$ & 0.78 & Sandy clay loam & Sand \\
Substrate texture & Sandy clay & San
\end{tabular}

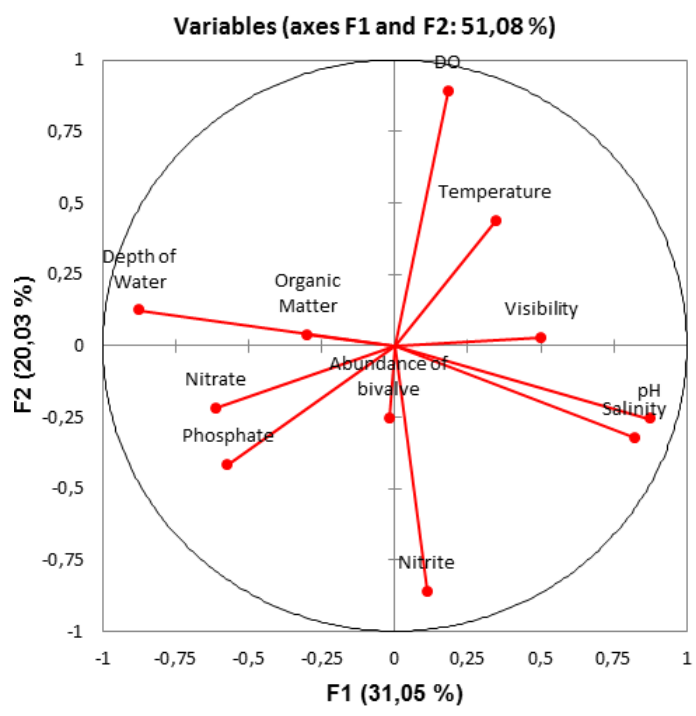

Figure 2. Result of Principal Component Analysis

\section{Principal Component Analysis}

Analysis of bivalve characteristics between research stations resulted in diversity of $31,05 \%$ at the first axis and $20,03 \%$ at the second axis. The total diversity of both axes was $51,08 \%$. Based on PCA analysis, formation of F1 positive and $\mathrm{F} 2$ positive axeses was $\mathrm{DO}$, temperature, and visibility. Salinity, $\mathrm{pH}$, and nitrite formed $\mathrm{F} 1$ positive and F2 negative axeses. Formation of F1 negative and F2 negative axises was the abundance of bivalves, phosphates, and nitrates. Grouping variables of organic matter and depth of water formed positive F1 and positive F2 axises. The most positive and strongly correlated parameters with bivalve abundance were nitrites. The abundance of bivalves was also positively correlated with nitrate, phosphate, salinity, and $\mathrm{pH}$. Positive correlations were characterized by an angle of $90^{\circ}$ or less than $90^{\circ}$ between bivalve abundance and water quality parameters. The smaller the angle formed, the stronger the correlation (Figure 2).

\section{Discussion}

Station 1 had the lowest species composition compared to other stations. Bivalves of the genus Anadara and Paphia were not found at station 1 . This was due to low salinity at this station so that the most abundant species were Meretrix meretrix. Bivalves from genus Anadara (Handayani et al. 2015) and Paphia (Zarkasyi et al. 2016) preferred waters with higher salinity. McKeon et al. (2015) stated that the grouping of bivalve communities occurred due to different salinity. Salinity affected production, distribution, lifespan, and migration orientation of bivalves (Islami 2013). Wibowo et al. (2017) stated that distribution of benthic macroinvertebrates is influenced by the interaction of habitats, physicochemical variables, structural and hydrological characteristics and human activities. Changes in characteristics, habitat and environmental resources of Tanjung Balai Asahan Waters can strongly influence patterns of spatial and in bivalves communities. Our results showed that the highest species composition corresponded to station 2. This high composition was possible since 
station 2 was located in the intertidal zone (littoral). Littoral zone is the transition zone between marine and land environment so that various invertebrate are present in this zone (Kang et al 2013; Hwang et al. 2015 and Setyaboma et al. 2015).

Average abundance of bivalves was the highest at station 3 and the lowest at station 2. Nitrate, nitrite and phosphate content at station 3 affected bivalve abundance as it was related to plankton as a food source. Nitrate, nitrite, phosphate is a nutrient for the growth of phytoplankton. Phytoplankton is a consumer of nitrogen compounds in seawater and takes nitrogen compounds gradually in the first order of nitrogen-nitrate $\left(\mathrm{NO}_{3}-\mathrm{N}\right)$, then nitrogen-nitrite $\left(\mathrm{NO}_{2}-\mathrm{N}\right)$, and finally nitrogenammonia $\left(\mathrm{NH}_{3}-\mathrm{N}\right)$ (Susana 2004). Phosphate is the primary productivity limiting factor so that if the phosphate content in water is high will increase growth phytoplankton in a short time (Susana 2004; Fathurrahman and Aunurohim 2014). Result showed that station 3 had the second highest content of nitrate, nitrite, and phosphate after station 1 . Station 1 had the highest nitrate and phosphate contents because at this station, the organic matter was also high. Station 1 was located in the estuary area so that high organic material, nitrate, nitrite and phosphate content was explicable. Estuary areas receive a high input of freshwater from the mainland. The high organic material in the estuary causes substrate texture in this area more refined than that in other locations. This is in line with the statement of Windusari et al. (2014) which states that areas with a smooth distribution of substrate particles contain higher organic matter. According to Kodama et al. (2012), the rich organic matter content is positively correlated with the proportion of dust and clay, but it is negatively correlated with the proportion of sand. This may cause the differences in the spatial distribution of benthic macrofauna as well as the population of individual in a community.

The most abundant species at stations 2 and 3 was $T$. sulcarius whereas the most abundant species in station 1 was M. meretrix. Abundance was related to the substrate texture and water quality at each station. Substrate texture in station 2 and 3 was sandy clay loam and sandy. Handayani et al. (2015) reported that Tapes sp. was a species with the highest abundance in location that has substrate textures with more sand content. This is evidenced by the highest abundance value of this species at station 3. Infaunal species such as T. sulcarius are collected in locations where the texture of the substrate often mixes with the sand that allowing this species to burrow (Masangcay and Lacuna 2017). Macrozoobenthos from classes of gastropod and bivalve tended to be found in the sand substrate type (Basyuni et al. 2018). The texture of sandy clay substrate was suitable for the life of $M$. meretrix. Setyobudiandini et al. (2004) stated that $M$. meretrix is a type of shellfish that is generally spread widely along fine sandy beaches. According to Veiga et al. (2014), texture of the substrate is one of the factors that affect the pattern of the distribution of macrozoobenthos including bivalves. In addition to the role as residence/habitat, substrate also serves as a hoard of nutrients, a place for gathering organic materials and a shelter from the threat of predators. Salinity also affected the abundance of $M$. meretrix. This type of shellfish is commonly found in estuary areas with low salinity. Salinity was inversely proportional to the abundance of this species. Increased salinity caused a decrease in abundance of $M$. meretrix (Setyobudiandini et al. 2004).

The value of diversity index can illustrate the productivity, ecosystem condition and ecological pressure (Fitriana 2006). The results showed that diversity index in Tanjung Balai Asahan Waters has low to moderate criteria. The low criteria on the Diversity Index showed that very low productivity, high stress and unstable ecosystem. According to Fitriana (2006), the moderate criteria on the Diversity Index shows high enough productivity, balanced ecosystem conditions, and moderate ecological pressures. Ecological pressure in the area with moderate diversity index was not too large. This suggested that water productivity was high enough that the balance of ecosystem conditions was maintained, indicated by the number of species found. The availability of food sources for bivalves is maintained when productivity is high. The location of this present study with moderate criteria on the diversity index was far from human activities. Stations 2 and 3 are in the intertidal zone while station 1 is at the estuary. The location of station 1 is adjacent to human settlements, fishing activities, ship traffic and waste disposal. Increased human activity caused a decline in ecosystem conditions due to household waste.

Low categorization of Evenness index indicated that individual distribution was not equal and there was a tendency for a community to be dominated by particular species (Basyuni et al. 2018). High Evenness Index in a community showed that the number of individuals of each species was almost the same and there were no dominating species. According to Kharisma et al. (2012), this index describes the ecological balance in a community, in which the higher the value of evenness index the better the quality of the environment for the life of bivalves. Evenness Index of 1 means that all existing samples of each species are nearly the same in numbers in a given environment (Fitriana 2006; Sihombing et al. 2017).

The results showed that there were dominant species at station 1. Domination indicated that species diversity in this area was low. Dominating species was $M$. meretrix because this species was known for its capability to adapt to highly fluctuated estuary zone. Estuary has lower salinity than that of sea waters due to freshwater input from the mainland. Organisms living in this area should have high adaptability to salinity changes. Estuary is also characterized by the high content of organic matter due to a high input of waste from the mainland including household waste, industrial waste or fertilizer used in agriculture. Fitriana (2006) stated that domination is the indication that each species has different capability of adapting to the environment.

Based on PCA analysis, bivalve abundance was positively correlated with nitrite, phosphate, nitrate, salinity, $\mathrm{pH}$, and visibility. On the other hand, abundance of bivalves was negatively correlated with depth of water, organic matter, temperature and DO. Nitrates, nitrites, and 
phosphates are nutrients in the water. Bivalves are filter feeder organisms that feed on the particles of organic matter and living things suspended in water. The presence of plankton in waters is influenced by nutrients, especially nitrates and phosphates. Nitrates and phosphates are nutrients for the growth of plants and algae in the waters (Effendie 2003). In addition, plankton especially phytoplankton is also a food source for bivalves (Arapov et al. 2010). The pH was also positively correlated with the abundance of bivalves and nutrients. The solubility of phosphate and nitrate after becoming phosphorus and nitrogen is strongly related to the reactions of redox and the degree of acidity $(\mathrm{pH})$. The results showed that areas with high salinity had high species composition and abundance. The visibility is related to the intensity of light penetrating the water column. If the visibility is high, the penetration of light is also high, causing the photosynthesis process takes places well so that the food sources, especially phytoplankton for Bivalvia is also abundant.

Negative correlations between bivalve abundance and depth were caused by low visibility values at the study sites from high sedimentation. The low water depth allowed sunlight to reach the bottom of the water so photosynthesis would take place. This resulted in the increasing of food source for bivalves in the form of plankton. The availability of food is one of the factors affecting the distribution of bivalves in the waters (Pawar and Al Tawaha 2017). Organic matter was also negatively correlated with the abundance of bivalve. This was because organic matter was also a source of food for bivalves. The predation of organic matter by bivalves caused the loss of organic matter in the waters. The cause of the decline of organic matter in waters was also caused by the degradation of organic matter into phosphorous and nitrate ions. Temperature and DO were also negatively correlated with the abundance of bivalve. The rising in temperature caused the bivalves to immerse themselves in the substrate. Bivalves have the ability to dig up substrates to shelter from predators as well as rising temperature. According to Ambarwati and Trijoko (2010), bivalves have shell shape, foot shape, chiffon and gills that are very suitable for digging the substrate and living as a suspension eater in the waters. The decrease in dissolved oxygen in the waters was caused by the activity of decomposition of organic material by bacteria (Kale 2016), temperature rise (Kale 2016) and the utilization of dissolved oxygen for respiration of aquatic organisms (Wilson 2010). A high bivalve abundance can cause a decrease in dissolved oxygen content in the water.

Based on the result of research, we can conclude that there were 16 species of bivalves from 7 families in Tanjung Balai Asahan Waters. Composition of bivalve species was highly in station 2 and the least was station 1 . The mean abundance of bivalves at stations 1,2 and 3 were $352 \pm 22 \mathrm{ind} / \mathrm{m}^{2}, 222 \pm 14 \mathrm{ind} / \mathrm{m}^{2}$, and $388 \pm 30,2 \mathrm{ind} / \mathrm{m}^{2}$, respectively. In general, the biodiversity index was categorized as low to moderate. The evenness index was categorized as low to high, while the dominance index indicated the dominant species in station 1. Based on PCA analysis, the abundance of bivalves was positively correlated with nitrite, nitrate, phosphate, salinity, and $\mathrm{pH} . \square$

\section{ACKNOWLEDGEMENTS}

We thank the Non BNBP fund of Universitas Sumatera Utara, Medan, Indonesia on TALENTA Research 2016 that funded this research with contract number: 21/UN5.2.3.1/PPM?SP/2016. $\square$

\section{REFERENCES}

Akhrianti I, Bengen DG, Setyobudiandini I. 2014. Spatial distribution and habitat preference of bivalvia in the Coastal Waters of Simpang Pesak Sub District, East Belitung District. J Trop Mar Sci Technol 6: 171185. [Indonesian]

Ambarwati R, Trijoko. 2010. Functional morphology of Paphia undulata Batik Shells (Bivalvia: Veneridae). Berk Penel Hayati 16: 83-87. [Indonesian]

Arapov J, Balic DE, Peharda M, Gladan ZN. Bivalve feeding-how and what they eat?. Ribarstvo 68: 105-116.

Azizi G, Akodad M, Baghour M, Layachi M, Moumen A. 2018. The use of Mytilus spp. mussels as bioindicators of heavy metal pollution in the coastal environment. A Review. J Mater Environ Sci 9: 11701181 .

Basyuni M, Gultom K, Fitri A, Susetya IE, Wati R, Slamet B, Sulistiyono N, Yusriani E, Balke T, Bunting P. 2018. Diversity and habitat characteristics of macrozoobenthos in the mangrove forest of Lubuk Kertang Village, North Sumatra, Indonesia. Biodiversitas 19: 311317.

Dabwan AHA, Taufiq M. 2016. Bivalves as bio-indicators for heavy metals detection in Kuala Kemaman, Terengganu, Malaysia. Indian J Sci Technol 9 (9): 1-6. DOI: 10.17485/ijst/2016/v9i9/88708.

Department of Fisheries and Marine of Sumatra Utara Province. 2014. Data Base Fisheries and Marine Province of North Sumatra. Department of Fisheries and Marine, North Sumatra Province, Medan. [Indonesian].

Dharma B. 2005. Recent \& Fossil Indonesian Shells. Conch Books, Germany.

Effendi H. 2003. Water Quality Study for Management of Water Resources and Environment. Kanisius. Yogyakarta.. [Indonesian]

Fathurrahman, Aunurohim. Phytoplankton Composition Study and Its Relationships with the Location of Mascara Shell Aquaculture (Pinctada maxima) in Sekotong waters, Nusa Tenggara Barat. J Teknik POMITS 3: 93-93. [Indonesian]

Fauzan M, Bakti D, Susetya IE, Desrita. 2018. Growth and exploitation rate of Anadara gubernaculum (Reeve, 1844) Arcidae Family in Asahan Aquatic of North Sumatra. IOP Conf Ser Earth Environ Sci. 122: 012105. DOI: 10.1088/1755-1315/122/1/012105.

Fitriana YR. 2006. Diversity and abundance of macrozoobenthos in mangrove rehabilitation forest in Great Garden Forest Ngurah Rai Bali. Biodiversitas 7: 67-72.

Guijarro RM, Romero I, Pachés M. 2015. A coastal pollution study: Heavy metal content in marine bivalves from the Spanish Mediterranean Coast. J Sci 5: 247-257.

Handayani MF, Muhlis ER, Gunawan. 2015. Abundance of Kerang Bulu (Genus: Anadara) in Labuhan Tereng Beach, Lombok Barat District. J Pijar MIPA 10: 12-17. [Indonesian]

Hwang H, Han JH, Lee S, Ryu YM, Paik IH, Min HK, Paek WK. 2015. Invertebrates fauna in the intertidal regions of Yubudo Island, South Korea. J Asia-Pac Biodiv 8: 66-71.

Intan A, Tanjung, Nurrachmi I. 2013. Kerang Darah (Anadara granosa) abundance in Coastal Water of Tanjung Balai Asahan, North Sumatera. Jomfaperika Unri 1: 1-10. [Indonesian]

Islami MM. 2013. Effect of Temperature and Salinity on Bivalves. Oseana 38: $1-10$.

Jagadis I, Rajagopal S. 2007. Age and growth of the venus clam Gafrarium tumidum (Roding) from South-East coast of India. Indian J Fish 54: 351-356. 
Kale VS. 2016. Consequence of temperature, pH, turbidity and dissolved oxygen water quality parameters. Intl Adv Res J Sci Eng Technol 3: 186-190.

Kang DW, Seo SY, Kang JS, Paek WK. 2013. Diversity of Intertida Benthic Invertebrate of Dokdo and Ulleung-do Island from Korea. J Asia-Pac Biodiv 6: 157-164.

Kharisma D, Adhi C, Azizah R. 2012. Ecological study of bivalves in the eastern part of Semarang in March-April 2012. J Mar Sci 1: 216-225.

Kodama K, Lee JH, Oyama M, Shiraishi H, Horiguchi T. 2012. Disturbance of benthic macrofauna in relation to hypoxia and organic enrichment in a eutrophic coastal bay. J Mar Environ Res 76: 80-89.

Krebs CJ. 1989. Ecological Methodology. Harper and Row Publisher, New York..

Manzo K, Estandarte MH, Dalipe RE, Ulangutan J, Lecera JM, Acob A, Diamalod J, Salmo W, Jumawan J. 2014. Survey and diversity of intertidal mollusks in Alabel and Maasim, Sarangani Province, Philippines. AACL Bioflux 7: 449-457.

Masangcay SIG, Lacuna MLDG. 2017. Molluscan (Gastropoda and Bivalvia) diversity and abundance in rocky intertidal areas of Lugait, Misamis Oriental, Northern Mindanao, Philippines. J Biodiv Environ Sci 11: 169-179.

McKeon CS, Tunberg BG, Johnston CA, Barshis DJ. 2015. Ecologica drivers and habitat associations of estuarine bivalves. PeerJ 3: e1348; DOI $10.7717 /$ peerj.1348.

Mikkelsen PM, Henne R. 2011. The Teacher-friendly Guide to Evolution using Bivalves as a Model Organism. The Paleontological Research Institution, Ithaca, New York.

Odum EP, Barrett GW. 2005. Fundamentals of Ecology. Thomson Brooks/Cole, Belmont, CA.

Pawar PR, Al-Tawaha ARMS. 2017. Species diversity and distribution of marine bivalves from coastal transitional ecosystem of Uran, Navi, Mumbai, India. Adv Environ Biol 11: 1-11.

Robson AA, Leaniz CGD, Wilson RP, Halsey LG. 2010. Behavioural adaptations of mussels to varying levels of food availability and predation risk. J Molluscan Stud 76: 348-353.
Setyaboma DB, Supriharyono, Ruswahyuni. 2015. The influence of beach distance and water substrate type against epifauna abundance in Panjang Island on Side West and South of Jepara. Diponegoro J Maquares 4: 20-28. [Indonesian]

Setyobudiandi I, Soekendarsih E, Vitner Y, Setiawati R. 2004. Bioecology of Lamis (Meretrix meretrix) from Marunda Coast. J Water Sci Fish Indonesia 11: 61-66. [Indonesian]

Sihombing VS, Gunawan H, Sawitri R. 2017. Diversity and community structure of fish, plankton and benthos in Karangsong Mangrove Conservation Areas, Indramayu, West Java, Indonesia. Biodiversitas. 18: 601-608.

Srimariana ES, Silaban BB, Lokollo E. 2015. Kerang manis (Gafrarium tumidum) from the coastal of Negeri Laha, Ambon Bay, potential as a source of minerals. Pros Sem Nas Masy Biodiv Indonesia 1: 843-847.

Susana T. 2004. Nitrogen Pollution Sources In Sea Water. Oseana 29: $25-$ 33. [Indonesian]

Veiga P, Rubal M, Cacabelos E, Maldonado C, Sousa-Pinto I. 2014. Spatial variability of macrobenthic zonation on exposed sandy beaches. J Sea Res 90: 1-9.

Walag AMP, Canencia MOP. 2016. Physico-chemical parameters and macrobenthic invertebrates of the intertidal zone of Gusa, Cagayan de Oro City, Philippines. AES Bioflux 8: 71-82.

Wibowo DN, Setijanto, Santoso S. 2017. Short Communication: Benthic macroinvertebrate diversity as biomonitoring of organic pollutions of river ecosystems in Central Java, Indonesia. Biodiversitas. 18: 671676.

Wilson PC. 2010. Water Quality Notes: Dissolved Oxygen. IFAS Extension University of Florida No. 8. University of Florida, Gainesville, FL.

Windusari Y, Sarno, Saleh E, Hanum L. 2014. Substrate Characteristics And Its Impact on Distribution of Mangrove Species: A Case Study in Sungai Barong Kecil in The Sembillang National Park at Banyuasin, South Sumatra. Journal of Biological Researches 19: 82-86.

Zarkasyi MM, Zayadi H, Laili S. 2016 Diversity and Distribution Pattern of Bivalves in Intertidal Zones Coastal Areas at Ujung Pangkah Gresik. Bioscience-Tropic 2: 1-10. [Indonesian] 